УДК 343.1

DOI https://doi.org/10.32837/pyuv.v0i5(34).664

\author{
А. Л. Терещенко \\ orcid.org/0000-0002-7153-4873 \\ кандидат юридичних наук (доктор філософії), доиент, \\ професор кафедри иивільного, господарського, адліністративного права \\ та правоохоронної ділльності, директор \\ Інституту права та суспільних відносин \\ Відкритого міжнародного університету розвитку людини «Україна» \\ В. П. Сердюк \\ orcid.org/0000-0003-4614-7991 \\ кандидат юридичних наук, доцент, \\ доцент кафедри иивільного, господарського, \\ адліністративного права та правоохоронної діяльності \\ Інституту права та суспільних відносин \\ Відкритого міжнародного університету розвитку людини «Україна» \\ С. В.Сердюк \\ orcid.org/0000-0002-5467-7207 \\ кандидат юридичних наук, \\ доцент кафедри конституиійного, адміністративного права \\ та соиіально-гуланітарних дисииплін \\ Інституту права та суспільних відносин \\ Відкритого міжнародного університету розвитку людини «Україна» \\ О. М. Балинець \\ orcid.org/0000-0001-9070-4201 \\ студент I курсу магістратури \\ Інституту права та суспільних відносин \\ Відкритого міжнародного університету розвитку людини «Україна»
}

\title{
ТЕХНІЧНЕ РОЗСЛІДУВАННЯ ТА ДОСУДОВЕ СЛІДСТВО В АВІАЦІЙНИХ ПОДІЯХ УКРАЇНИ
}

Постановка проблеми. Експерти незалежної державної установи - Національного бюро з розслідування авіаційних подій та інцидентів з цивільними повітряними суднами (далі - Національне бюро) та органи досудового розслідування у своїй діяльності повинні постійно вирішувати питання взаємодії через взаєморозуміння щодо огляду місця події, призначення та проведення різних видів авіаційно-інженерних експертиз та інших процесуальних дій, які врегульовують меморандумами, що протирічить фундаментальним принципам технічного розслідування та кримінального провадження.

Законодавчо не врегульовані конкретні алгоритми дій представників цих органів під час спільного дослідження авіаційної події впливають на рівень якості їхньої роботи.

Мета публікації - за допомогою досліджень надати висновок про відповідність фундаментальних процесуальних положень одночасного проведення технічного розслідування авіаподії експертною установою у взаємовідносинах із досудовим слідством; на підставі аналізу вітчизняного та зарубіжного законодавчого досвіду, практики технічного та досудового розслідування запропонувати законодавче врегулювання спільного, одночасного державного технічного розслідування у взаємодії з досудовим розслідуванням авіаційних подій на території нашої країни.

Аналіз останніх досліджень і публікацій. Проблеми дослідження авіаційних подій, забезпечення процесу доказування під час їх розслідування, розвиток авіаційно-інженерних судових експертиз у своїх працях висвітлювали О.І. Мотлях, Ю.В. Корнєєв, Ю.А. Задорожний, В.П. Верченко, А.С. Бичков та інші. Дослідженню проблеми законодавчого врегулювання взаємовідносин між органами досудового розслідування та Національним бюро з розслідування авіаційних подій та інцидентів із цивільними повітряними суднами (експертною установою) присвятили свої роботи: В.П. Сердюк, Є.В. Сердюк, О.О. Фаст. Але практика потребує додаткових наукових досліджень, висновків та пропозицій.

Виклад основного матеріалу. Аналіз стану вітчизняного законодавчого врегулювання дослідження авіаційних подій, практики його використання органами досудового розслідування та 
органом технічного розслідування авіаційних подій із цивільними повітряними суднами дає підстави зробити висновок про наявність постійної, ще не вирішеної проблеми - законодавчого врегулювання дієвої взаємодії між цими органами.

Вітчизняним законодавством не конкретизовані рекомендації 13-го Додатку видання червня 2016 року до Конвенції про міжнародну цивільну авіацію від 7.12.1944 року щодо незалежного розслідування технічних причин авіаційних подій і інцидентів від офіційного слідства в напрямі взаємодії відомчого та державного розслідування. Це ж питання не врегульовано і підзаконними актами. Але для вирішення завдань указаних органів їхні співробітники домовляються між собою усно або укладають меморандуми, що закладає негативні тенденції для результативного судового провадження, де є зацікавлені сторони з прагненням до вирішення своїх різних завдань. Тому практики повинні фундаментально, на законодавчому рівні оформлювати свої рішення, які б давали конкретні відповіді на поставлені перед ними питання.

Результатом нашого попереднього дослідження були пропозиції щодо доповнення вітчизняного кримінального процесуального законодавства в напрямі укріплення процесуальної самостійності державних експертів Національного бюро, наслідком впровадження яких не могли настати матеріальні збитки для держави. Наприклад: зміна назви Національного бюро на бюро технічного розслідування; доповнити ч. 8 до ст. 237 КПК України щодо узгодження спільного огляду місця авіаційної події з конкретними алгоритмами дій слідчого досудового слідства, прокурора з державним експертом Національного бюро та з приводу фіксації, вилучення речей і проведення по них експертного дослідження; законодавчого закріплення угод, передбачених ст. 468 КПК України, між прокурором, керівником органу досудового розслідування та директором Національного бюро щодо дотримання принципу незалежності обох сторін, виконання ними вимог КПК України під час дослідження технічних причин авіаподії; запропонована необхідність законодавчої заборони допиту державного експерта Національного бюро з приводу відомостей, які стали йому відомі під час розслідування авіаційної події, щодо вини особи.

Вказані пропозиції закріпляють процесуальну незалежність державного експерта Національного бюро в напрямі розвитку рекомендацій Додатку 13 до Конвенції IКАО щодо незалежного розслідування технічних причин авіаційних подій і інцидентів та не порушують принципи незалежності слідчого та прокурора. Такі нововведення не потребують додаткових державних матеріальних затрат, але є необхідність глибшого наукового вивчення вітчизняного та зарубіжного законодавчого досвіду слідчої, судової та експертної практики
Національного бюро щодо взаємодії цих органів для покращення якості їхньої роботи [1, с. 126].

Нормативним підтвердженням цього є те, що Україна, будучи членом Міжнародної організації цивільної авіації (ІКАО), повинна виконувати свої міжнародні зобов'язання відповідно до вимог ст. 26 Додатку 13 до Конвенції ІКАО щодо проведення технічного розслідування авіаційних подій так, наскільки це допускає вітчизняне законодавство, і як врегульована дана процедура у сфері розслідування авіаційних подій у значенні цієї статті Конвенції [2, с. 1].

Повітряний кодекс України, Положення про Національне бюро з розслідування авіаційних подій та інцидентів з цивільними повітряними суднами визначили та закріпили Національне бюро як самостійну державну експертну структуру, на яку покладено технічне розслідування авіаційних подій із цивільними суднами [3. с. 3].

Підзаконним актом, згідно з п. 3 Положення про Національне бюро з розслідування авіаційних подій та інцидентів 3 цивільними повітряними суднами, затвердженого Постановою Кабінету Міністрів України від 13 травня 2020 року № 417, визначено, що Національне бюро є державною спеціалізованою експертною установою з розслідування авіаційних подій та інцидентів 3 цивільними повітряними суднами в Україні на рівні інших, утворених Кабінетом Міністрів установ [4, с. 1$]$.

Звідси випливає, що взаємодія державного експерта Національного бюро з прокурором, слідчим під час огляду місця авіаційної події, призначення та проведення судово-експертного дослідження механізму обставин авіаційної події та інших процесуальних дій, які стосуються розслідування авіаподії, може і повинна грунтуватися на фундаментальних вимогах Кримінального процесуального кодексу України та не протирічити ст. 26 Додатку 13 до Конвенції IКАО, тому що саме таким чином врегульована вітчизняна процедура у сфері розслідування авіаційних подій.

Автори вважають також, що наявність міжнародного договору, в якому Україна є його учасником (ст. 9 ч. 4 КПК України), відсутні елементи міжнародного кримінального процесуального врегулювання, отже, не можуть мати юридичної сили по відношенню до вітчизняного кримінального процесуального законодавства.

Ці висновки підтверджуються вимогами Кримінального процесуального кодексу України, де закріплено процесуальний статус прокурора, який має чітко визначені законом повноваження, серед яких заключення меморандумів, договорів з іншими правоохоронними органами не допускаються.

Так, згідно зі ст. 36 КПК України прокурор, здійснюючи свої повноваження відповідно до вимог Кодексу, є самостійним у своїй процесуальній 
діяльності, втручання в яку осіб, що не мають на те законних повноважень, забороняється. Органи державної влади, органи місцевого самоврядування, підприємства, установи та організації, службові та інші фізичні особи зобов'язані виконувати законні вимоги та процесуальні рішення прокурора. Прокурор здійснює нагляд за додержанням законів під час проведення досудового розслідування у формі процесуального керівництва досудовим розслідуванням [5, с. 23].

Відповідно до ст. 40 ч. 1, 4, 5 слідчий несе відповідальність за законність та своєчасність здійснення процесуальних дій. Він зобов'язаний виконувати доручення та вказівки прокурора, які надаються в письмовій формі. Невиконання слідчим законних вказівок та доручень прокуроpa, наданих у порядку, передбаченому Кодексом, тягне за собою встановлену законом відповідальність. Слідчий, здійснюючи свої повноваження відповідно до вимог КПК, є самостійним у своїй процесуальній діяльності, втручання в яку осіб, що не мають на те законних повноважень, забороняється. Органи державної влади, органи місцевого самоврядування, підприємства, установи та організації, службові особи, інші фізичні особи зобов'язані виконувати законні вимоги та процесуальні рішення слідчого [5, с. 27]. Отже, слідчий, прокурор, дізнавач згідно з КПК відповідають за розслідування та координацію дій 3 іншими органами держави таким чином, щоб не порушувати приписи закону. У разі виникнення спільних інтересів двох відомств їх можна врегульовувати в межах процесуального закону.

Таким чином, ведучі у кримінальному провадженні під час досудового розслідування не мають процесуальної можливості проводити процесуальні дії на підставі меморандумів (угод про наміри) між установами, зацікавленими в розслідуванні авіаційних подій.

На нашу думку, потрібне законодавче врегулювання діяльності Національного бюро з визначенням організації та статусу органу і слідчих технічного розслідування авіаційних подій, із закріпленням спільної взаємодії представників цих органів на підставі визначеної законом угоди з прерогативою положення щодо досудового слідства.

Серед основних принципів взаємодії в теорії криміналістики виділені: відповідальність слідчого та експерта (спеціаліста) за швидке, повне й неупереджене розслідування кримінальних правопорушень, їх самостійність у процесуальній діяльності, втручання в яку осіб, що не мають на те законних повноважень, забороняється; активне використання методик, наукових і технічних досягнень у попередженні, виявленні та розслідуванні кримінальних правопорушень; дотримання загальних засад кримінального провадження.
Ю.І. Азаров, Є.О. Рафальський робили висновки про те, що на початковому етапі досудового розслідування робота щодо вдосконалення взаємодії в діяльності органів внутрішніх справ потребує постійного моніторингу, дискусійності та обміну досвідом видатних учених-науковців та практиків, зокрема, це пояснюється «молодістю» Кримінального процесуального кодексу України та необхідністю адаптації відповідно до його положень нормативного масиву відомчих документів [6, с. 88].

Аналіз вітчизняноїзаконодавчоїпрактикипідтверджує, що наша держава має досвід урегулювання діяльності експертної установи Законом України «Про державну експертизу землевпорядної документації. Цей Закон визначає поняття державної експертизи землевпорядної документації як діяльність, метою якої є дослідження, перевірка, аналіз та оцінка об’єктів експертизи на предмет їх відповідності вимогам законодавства, встановленим нормам і правилам, а також підготовка обгрунтованих висновків для прийняття рішень щодо об'єктів експертизи, що є важливим і для діяльності державного експерта Національного бюро.

У Законі визначаються завдання, принципи державної експертизи (ст. ст. 4, 5), об'єкти та суб'єкти державної експертизи (ст. ст. 6, 7). Встановлено органи, що здійснюють регулювання у сфері державної експертизи, до яких віднесені: Верховна Рада України, Кабінет Міністрів України, центральний орган виконавчої влади, що забезпечує формування державної політики у сфері земельних відносин, спеціально уповноважений орган виконавчої влади у сфері державної експертизи, інші органи виконавчої влади, органи місцевого самоврядування в межах повноважень, визначених законом, що є необхідним і для діяльності Національного бюро (ст. 16). До повноважень Верховної Ради України у сфері державної експертизи належать: прийняття законів у сфері державної експертизи; визначення засад державної політики у сфері державної експертизи; вирішення інших питань у сфері державної експертизи відповідно до Конституції України (ст. 17 цього Закону).

Визначається статус державного експерта як спеціаліста, який має вищу освіту, відповідну спеціальність, кваліфікацію і професійні знання, володіє навичками аналізу експертної інформації, а також має практичний досвід у відповідній сфері не менше трьох років (ст. 23), його права та обов'язки (ст. ст. 24, 25). Визначаються гарантії незалежності експерта державної експертизи, яка забезпечується: проведенням державної експертизи у встановленому законом порядку; свободою вибору форм і методів експертного аналізу й оцінки та викладенням особистої думки 
з питань проведеного аналізу; забороною втручатися будь-кому в проведення державної експертизи, за винятком визначених законом випадків; захистом порушених прав експерта у встановленому законом порядку [7, с. 1-18].

Отже, визначений Законом статус органу, його співробітників може бути прикладом запозичення та впровадження в авіаційній галузі для законодавчого врегулювання Національного бюро, яке є обов'язковим учасником розслідування авіаційних подій за рекомендацією міжнародної авіаційної організації ІКАО, членом якої є Україна, котра згідно з міжнародним договором повинна незалежно розслідувати авіаційні події водночас із представниками досудового розслідування.

Державний експерт Національного бюро державної установи, маючи процесуальний статус галузевого призначення, визначений системним законом, у разі необхідності зможе діяти самостійно, дотримуючись установлених законом прав та обов'язків, і ефективно виконувати поставлені завдання.

Наше дослідження не буде повним без аналізу міжнародного досвіду законодавчого врегулювання діяльності та взаємодії органів досудового слідства та тих, що досліджують технічну причину авіаційної події і діють відповідно до Конвенції IКАО.

У ФРГ діє Федеральне бюро розслідування авіаційних подій Німеччини BFU (ФБРАП), яке підпорядковується Федеральному міністерству транспорту і відповідає за розслідування авіаційних подій із цивільними літаками і серйозних інцидентів у Німеччині. Основною метою BFU є: підвищення безпеки польотів шляхом визначення причин авіаційних подій та серйозних інцидентів і вироблення рекомендацій з безпеки, спрямованих на запобігання їх повторення. Це не розподіл провини або відповідальності.

Нормативно-правовою базою розслідування нещасних випадків та інцидентів у цивільній авіації Німеччини є Закон, що стосується розслідування нещасних випадків та інцидентів, пов'язаних з експлуатацією цивільних літаків, від 26 серпня 1998 р. Він узгоджується з Додатком 13 до Конвенції IКАО і Регламентом (ЄС) № 996/2010 Свропейського Парламенту і Ради від 20 жовтня 2010 року про розслідування та запобігання аваріям й інцидентам у цивільній авіації та про скасування Директиви 94/56 /ЄС.

На додаток до Закону було адаптовано Положення про повідомлення про авіаційні аварії та аварії (§ 7 LuftVO), згідно з яким інформування інших органів влади чи обгрунтування фактів, установлених у ході розслідування, припущення про кримінальне правопорушення у зв'язку з аварією або серйозними порушеннями експлуатації цивільних літаків або що має важливе значення, федеральне агентство повідомить особу, відповідальну за авіаційну безпеку, орган влади та відповідні правоохоронні органи.

Згідно з 12 Положення місце аварії повинно бути ефективно відгороджене від третіх осіб якомога раніше. Слідчий приймає рішення про доступ до огородженого місця аварії в тісній співпраці з відповідним правоохоронним органом.

Відповідно до § 13 Про звільнення місця аварії літака або його частин, вантажу слідчий, який відповідає за будь-яких потерпілих, приймає рішення в тісній співпраці з компетентним органом [8, с. 1-18].

Отже, закон алгоритму дій не закріпив, але передбачає та врегульовує, хоча й не конкретно, тісну співпрацю між слідчим та правоохоронним органом або компетентним органом.

В Ісландії діє Закон про розслідування транспортних аварій, який набрав чинності 1 червня 2013 р., з останньою зміною від 1 січня 2019 року. Метою цього Закону є зменшення кількості нещасних випадків та підвищення безпеки на транспорті шляхом посилення та вдосконалення досліджень нещасних випадків. Розслідування згідно з цим Законом має бути спрямоване лише на виявлення причин транспортних аварій та інцидентів, а не на розподіл вини та відповідальності, з метою зменшення ризику подібних аварій та інцидентів і наслідків подібних аварій. Відповідно до ст. 3 п.п. 10, 11, 12 цього Закону діє слідчий комітет з питань транспортних аварій та директор з розслідування - особа, яка контролює конкретну категорію розслідування нещасних випадків. Згідно зі ст. 10 Закону слідчий комітет відповідає за розслідування та координацію дій з іншими державами, які мають сильний інтерес, поки не буде прийнято спільне рішення про те, яка держава повинна бути головною державою, що розслідує, що може бути запозичено для вітчизняного впровадження [9, с. 1].

Врегулювання взаємодії між слідчим комітетом та досудовим слідством нами не виявлено, але закріплене спільне рішення без обгрунтування його формування та прийняття.

В Іспанії діє Комісія з розслідування нещасних випадків та інцидентів у цивільній авіації (CIAIAC), яка створена при підсекретаріаті Міністерства громадських робіт і є офіційним органом, відповідальним за розслідування нещасних випадків та інцидентів, що трапляються на території Іспанії.

Розслідування має виключно технічний характер, його кінцевою метою є запобігання майбутнім аваріям та інцидентам, і воно не спрямоване на визначення або встановлення вини чи будь-якої відповідальності [10, с. 1].

Взаємодії Комісії з правоохоронними органами нами не встановлено. 
Висновки. Проведене нами дослідження не дало позитивних результатів на встановлення законодавчого врегулювання алгоритму взаємодії державного експерта, а в міжнародному праві - слідчого із встановлення технічної причини авіаподії зі слідчим досудового слідства або компетентними органами, які встановлюють вину особи в скоєнні кримінального правопорушення.

Надалі є необхідність дослідження законодавчого врегулювання взаємодії, координації дій та регламентування двостороннього рішення з досудовим слідством співробітників Національного бюро, які мають спільний інтерес у вирішенні питань розслідування авіаподії, та хто повинен бути головним під час проведення конкретних процесуальних дій, наприклад: вилучення пишучих приладів на місці події, призначення і проведення відповідних експертиз, опитування очевидців, збору речових доказів та надання пропозицій щодо їх законодавчого вирішення.

На підставі раніше проведених досліджень та встановлених і аналізованих законодавчих актів, запозичуючи вітчизняну та міжнародну законодавчу практику, пропонуємо:

прийняти Закон України «Про Національне бюро з розслідування авіаційних подій та інцидентів з цивільними повітряними суднами», яким визначити організацію його утворення, статус слідчого у сфері технічного дослідження авіаційних подій та інцидентів, установити алгоритм його взаємодії з представниками досудового розслідування та іншими державними органами та установами під час дослідження місця авіаційної події, вилучення необхідних матеріалів для дослідження, проведення відповідних експертиз, опитування очевидців, чітко визначаючи алгоритм самостійних та спільних дій, не порушуючи принцип незалежності з представниками органів досудового розслідування та Національного бюро.

Таке рішення закладе правову основу для законодавчого забезпечення взаємодії дослідника технічної причини авіаподії та слідчого досудового слідства для спільного і незалежного виконання кожним завдань, визначених законами.

\section{Jimepamypa}

1. Сердюк В.П., Сердюк Є.В., Фаст О.О. Актуальні питання законодавчого врегулювання розслідування авіаційних подій в Україні. Збірник наукових праиь «Актуальні проблеми держави і права». 2018. № 80. C. $126-132$.

2. Додаток 13 до Конвенції про міжнародну цивільну авіацію від 7.12. 1944 року. Розслідування авіаційних подій і інцидентів. Видання одинадцяте від липня 2016 року. Замінюе всі попередні видання. URL: https://airspot.ru/library/book/ikao-prilozhenie13-k-konventsii-o-

3. Повітряний кодекс України. Прийнятий 19.05.2011 р. Редакція від 18.12.2017 р., № 3393-VI.
Відомості Верховної Ради України (ВВР), 2011. № $48-49$. Ст. 536.

4. Положення про Національне бюро з розслідування авіаційних подій та інцидентів 3 цивільними повітряними суднами, затверджене постановою Каб. Міністрів України від № 228 від 21 березня 2012 року. URL: http://zakon3.rada.gov.ua/laws/show/ 228-2012-п

5. Кримінальний процесуальний кодекс України. Верховна Рада України; Кодекс від 13.04.2012 р. № 4651-VI (Редакція станом на 08.10.2016р.).

6. Азаров Ю.І. Рафальський Є.О. Особливості взаємодії слідчого з експертом (спеціалістом) на початковому етапі досудового розслідування. Юридична наука. № 10/201. С. 87-96.

7. Закон України Про державну експертизу землевпорядної документації. Відомості Верховної Ради України (ВВР). 2004. № 38. Ст. 471. С. 1-18.

8. ФРГ. Закон про розслідування авіаційних подій від 26 серпня 1998 (Бюлетень федеральних законів I, стор. 2470), останній раз змінений пунктом 9 т. 5. Закону від 10 березня 2017 року (Вісник ФЗ І стор. 410). URL: https://www.icao.int/SiteAssets/html/Links_ RU.html

9. Закон про розслідування транспортних аварій Ісландії від 1 червня 2013 р., с поправкою : Закон 141/2019 від 1 січня 2020 року. С. 1. URL: https://www.althingi.is/lagas/nuna/2013018.html

10. Закон Іспанії 1/2011 від 4 березня, який встановлює Державну програму експлуатаційної безпеки цивільної авіації та змінює Закон 21/2003 від 7 липня про безпеку повітря. C. 1. URL: https://www.icao.int/ SiteAssets/html/Links_RU.html

\section{Анотація}

Терещенко А. Л., Сердюк В. П., Сердюк Є. В., Балинець О. М. Технічне розслідування та досудове слідство в авіаційних подіях України. - Стаття.

У статті проведено наукове дослідження щодо спільного технічного розслідування та досудового слідства авіаційних подій в Україні та взаємодія співробітників цих органів під час вивчення обставин та обстановки авіаційної події.

Проаналізована практика відомчої, незалежної державної установи - Національного бюро з розслідування авіаційних подій та інцидентів з цивільними повітряними суднами та органи досудового слідства, які у своїй діяльності повинні постійно вирішувати питання взаємодії через взаєморозуміння, а не законодавство щодо спільної роботи під час огляду місця події, призначення та проведення різних видів авіаційно-інженерних експертиз та інших процесуальних дій, які врегульовують меморандумами, що протирічить фундаментальним принципам технічного розслідування та кримінального провадження. Відсутність законодавчо врегульованих, конкретних алгоритмів дій представників цих органів під час спільного дослідження авіаційної події впливають на рівень якості їх роботи.

Досліджується вітчизняний досвід законодавчого врегулювання взаємодії під час спільного дослідження авіаподії відомчою державною установою та органами досудового слідства, порівняно вітчизняний досвід 3 міжнародним досвідом законодавчого врегулювання діяльності та взаємодії органів досудового слідства та тих, що досліджують технічну причину авіаційної події і діють відповідно до Конвенції ІКАО.

Запропоновано проводити додаткові наукові дослідження законодавчого врегулювання взаємодії, координацію дій та регламентування спільного 
рішення 3 досудовим слідством співробітників Національного бюро, які мають спільний інтерес у вирішенні питань розслідування авіаподії.

Також запропонованоприйняти Закон України «Про Національне бюро з розслідування авіаційних подій та інцидентів з цивільними повітряними суднами", яким визначити організацію його утворення, статус слідчого у сфері технічного дослідження авіаційних подій та інцидентів, чітко визначаючи напрями самостійних та спільних дій, не порушуючи принцип незалежності, 3 представниками органів досудового слідства та Національного бюро.

Ключові слова: орган досудового слідства, Національне бюро з розслідування авіаційних подій та інцидентів із цивільними повітряними суднами, взаємодія, міжнародний договір, зарубіжний досвід.

\section{Summary}

Tereshchenko A. L., Serdyuk V.P., Serdyuk E. V., Balinets O. M. Technical investigation and pre-trial investigation in aviation events in Ukraine. - Article.

The article conducts a scientific study on the joint technical investigation and pre-trial investigation of aviation events in Ukraine, and the interaction of employees of these bodies during the study of the circumstances and circumstances of the aviation event. The practice of a departmental, independent state institution - the National Bureau for Investigation of Aviation Incidents and Incidents with Civil Aircraft and pre-trial investigation bodies, which in their activities must constantly address issues of cooperation through mutual understanding, rather than legislation on joint work conducting various types of aeronautical engineering examinations and other procedural actions regulated by memoranda, which contradicts the fundamental principles of technical investigation and criminal proceedings. The lack of legally regulated, specific algorithms of actions of the representatives of these bodies during the joint investigation of the aviation event affect the level of quality of their work. The domestic experience of legislative regulation of interaction during a joint investigation of an air accident by a departmental government agency and pre-trial investigation bodies was studied, compared with domestic experience with international experience of legislative regulation of interaction and interaction of pre-trial investigation bodies and those investigating technical causes and operating in accordance with ICAO Convention. It is proposed to conduct additional research on the legislative regulation of interaction, coordination of actions and regulation of joint decisions with the pre-trial investigation of employees of the National Bureau who have a common interest in addressing the investigation of the accident. Also, to adopt the Law of Ukraine "On the National Bureau for Investigation of Aviation Incidents and Incidents with Civil Aircraft" which will determine the organization of its formation, the status of investigator in the field of technical investigation of aviation events and incidents, clearly defining areas of independent and joint action representatives of the pretrial investigation bodies and the National Bureau.

Key words: pre-trial investigation body, National Bureau for Investigation of Aviation Incidents and Incidents with Civil Aircraft, interaction, international agreement, foreign experience. 